\title{
The Natufian Culture and the Origin of the Neolithic in the Levant
}

\section{Citation}

Bar-Yosef, O., and F. Valla. 1990. "The Natufian Culture and the Origin of the Neolithic in the Levant." Current Anthropology 31 (4) (January): 433.

\section{Published Version}

doi:10.1086/203867

\section{Permanent link}

http://nrs.harvard.edu/urn-3:HUL.InstRepos:12210882

\section{Terms of Use}

This article was downloaded from Harvard University's DASH repository, and is made available under the terms and conditions applicable to Other Posted Material, as set forth at http:// nrs.harvard.edu/urn-3:HUL.InstRepos:dash.current.terms-of-use\#LAA

\section{Share Your Story}

The Harvard community has made this article openly available.

Please share how this access benefits you. Submit a story.

\section{Accessibility}




\section{The Natufian Culture and the Origin of the Neolithic in the Levant ${ }^{1}$}

\author{
O. BAR-YOSEF AND F. VALLA \\ Department of Anthropology, Harvard University, \\ Cambridge, Mass. 02138 , U.S.A./Centre des \\ Recherches Français de Jerusalem, CNRS, P.O. Box \\ 547, Jerusalem 91004, Israel. 5 III 90
}

The Natufian culture occupies a special place in the evolution of human societies in the Near East, namely, that of the threshold to the emergence of farming communities. The idea that the Natufians were the earliest farmers is as old as the original discovery of their cultural remains by Garrod (1932). What seemed at the time an intuitive suggestion is now considered perhaps the right interpretation (Moore 1982, Unger-Hamilton I989). The shift from hunting-and-gathering with some horticulture to a true farming economy seems a logical continuum (Henry I 989). The fact that most of the hard evidence from the Natufian sites comes from the Early or even Middle Natufian (Valla I984), which predates the Early Neolithic by at least 800 radiocarbon years, is rarely taken into account (Bar-Yosef and Belfer-Cohen 1989). The discovery of early farming sites in the Jordan Valley and the adjacent hilly areas on both the east and the west side of the Rift Valley has made it clear that the origins of wheat and barley agriculture were in the southern Levant (van Zeist I988, Bar-Yosef I989). Thus the need to understand cultural processes in and around the Natufian homeland (Stordeur I98I) has assumed special importance.

Explaining not only how but also why the Natufian culture emerged from a world of hunter-gatherers apparently not much different in material culture from their contemporaries has become the concern of a number of scholars. Henry ( 1989 ) has produced perhaps the most substantial discussion, which takes population dynamics into account. As more and more new data have been retrieved from Natufian sites, pollen cores, and faunal collections, the need for direct international discussion has become obvious, especially since many scholars working in various countries of the Near East have no such communication because of the political situation. The participants in the conference on the Natufian held at the Centre des Recherches Archéologiques, Sophia Antipolis, Valbonne, June 6-8, 1989, were archaeologists, zooarchaeologists, palynologists and palaeobota-

I. (c) 1990 by The Wenner-Gren Foundation for Anthropological Research. All rights reserved 00I I-3204/90/3104-0005\$1.00. We thank the Wenner-Gren Foundation for Anthropological Research (New York), the American School for Prehistoric Research (Peabody Museum, Harvard University), the CNRS, and the Ministry of Foreign Affairs (Paris) for making possible the conference reported here. We also thank Mme. Pallier and L. Meignen, who helped in organizing it. nists, and microwear analysts. The following is a summary of the main topics discussed. The papers of the conference will soon be published.

Paleoenvironments. After recent coring in the Hula Valley, S. Bottema and U. Baruch were able to suggest a general climatic sequence for the Levant from about I 5,000 to 8,000 B.P. derived from their densely sampled pollen cores. While previous work in the Ghab marshes of the northern Orontes Valley was taken into account, it seems that the conflict in chronological interpretation between the Hula Valley and the Ghab sequence may result from the paucity of radiocarbon dates from the Ghab. The recent palynological profile from the Hula Basin, as yet dated by only two readings, correlates well with the earlier palynological graph from another borehole in the Hula Valley done by H. Tsukada, which is dated by 16 radiocarbon samples (Bottema and van Zeist I98I, Cowgill I969). Bottema views the Ghab sequence as well founded and considers the colder Pleniglacial period to have been longer in the northern Levant. Warming led to the expansion of forest vegetation first in the southern Levant, where a peak was reached around I I,500 B.P. The later slight decrease in arboreal pollen in the Hula Basin possibly represents the Younger Dryas, and a slight increase marks the onset of wetter Holocene conditions probably around Io,000 B.P. The pollen evidence indicates that the Early Holocene was wetter than the Mid- and Late Holocene. Tchernov's (Noy, Schuldenrein, and Tchernov I980) faunal analysis of large samples from Netiv Hagdud and Gilgal, Early Neolithic (Pre-Pottery Neolithic A) sites I $3 \mathrm{~km}$ north of Jericho in the Lower Jordan Valley, supports this climatic interpretation. He concludes that the only way to account for the presence there of so many diverse freshwater avian and rodent species is in terms of the former existence of bodies of fresh water nearby. Palynological evidence from Netiv Hagdud studied by Leroi-Gourhan and Darmon (I987) reflects the presence of a rich aquatic flora and corroborates the geomorphological evidence produced by Schuldenrein and Goldberg (I98I). While there is disagreement about the value of pollen data derived from archaeological sites, it is of interest that Leroi-Gourhan and Darmon have reached conclusions similar to those based on the pollen cores from the Hula Valley.

In sum, the various lines of evidence demonstrate cold, wet conditions during the Geometric Kebaran/ Mushabian period (I 4,000-I 2, 800/I 2,500 B.P.) preceding the Natufian, a dry spell during the very Early Natufian, a steady increase in arboreal pollen during the Early Natufian, and an ensuing drier period in the Late Natufian (Younger Dryas). An increase in humidity is documented for the Early Holocene both from Mureybet in the middle Euphrates Valley in northern Syria and from the Lower Jordan Valley.

The archaeology of Natufian sites. The presentation of archaeological reports was an inevitable mixture of final site reports from the excavations carried out in the I $960 \mathrm{~s}$ and I970s and preliminary reports on new excavations or sites discovered in recent surveys. 
J. Perrot described and discussed the types of burials exhumed in the excavations of Ain Mallaha (Eynan), now fully published (Perrot and Ladiray 1988). Skeletal remains were often found in flexed and semiflexed position, rarely with body decorations made of series of Dentalium shells. According to Solivers-Massei (I988), the population of Ain Mallaha demonstrates marked sexual dimorphism, often greater stature than among other Natufian groups, and greater morphological robusticity (which Ferembach [1976] has attributed to dietary differences).

B. Byrd described the scanty Natufian remains excavated under the Pre-Pottery Neolithic B village of Beidha, dated to I 2,500 B.P. (Byrd I 989). He stressed that, contrary to earlier reports, there is no evidence for the use of mud bricks by the Natufian occupants. In an additional communication he described the potential of another site recently discovered in a tributary of Wadi Hasa (southern Jordan), where numerous mortars were found in what seems to be a rich Early Natufian occupation.

A paucity of Natufian occurrences was reported by A. Garrard for the Azraq Basin (Garrard et al. I987) and by A. Betts for the Black Desert in Jordan. The only site in the Azraq Basin at which a few secondary burials were uncovered was destroyed by subsequent development activities. Ephemeral Natufian occupations left only impoverished lithic assemblages in the Black Desert, where water sources are only seasonal (Betts I982).

Hayonim Cave was excavated in the late 1960 and I 970 os by O. Bar-Yosef, E. Tchernov, and B. Arensburg. Most of the lithics and the bone tools (Bar-Yosef and Goren 1973) have recently been studied by A. BelferCohen (I988), who discussed typological and technological changes through time on the basis of samples from the internal stratigraphy of the Natufian deposits. F. Valla, who is currently excavating the Hayonim Terrace, stressed the advantages of meticulous horizontal excavation in tracing hearths, burials, dumping zones, and the remains of houses. The skeletal material is being analyzed by F. Le Mort. A selected sample of flint artifacts is being studied by $\mathrm{H}$. Plisson to determine their functions.

Work in the Lower Jordan Valley was represented by the current excavations at Salibiya I, carried out jointly by P. Crabtree, D. Campana, and A. Belfer-Cohen. At this site was found a small incised pebble, one of the rare Late Natufian art objects. Additional art objects were described by $T$. Noy from the excavations of Nahal Oren, a terrace site dug in the r 960 s and the early r 970 s and known mainly from preliminary reports.

Following the description of the Natufian sites from what is considered to be the homeland of this archaeological entity, the marginal regions were discussed. N. Goring-Morris described the Late Natufian sites from the Negev highlands and went on to report on the latest Natufian adaptation to increasing aridity, known as the Harifian (Scott 1977, Magaritz and Goodfriend 1987, Goring-Morris 1987). It would appear that the disappearance of the Harifian from a region of about $25,000 \mathrm{~km}^{2}$ was due to the failure of its subsistence strategy. Although one might hypothesize that its bear- ers joined the successful Early Neolithic (Pre-Pottery Neolithic A) farming communities in the Jordan Valley or southern Jordan, it seems more probable that the onset of the wet Early Holocene conditions, which must have improved the success of early cultivators, did not entirely coincide with the disappearance of the Harifian, as has been indicated recently by $\mathrm{C}^{14}$ dates obtained from Pre-Pottery Neolithic A sites in the Jordan Valley (Bar-Yosef 1989).

The other marginal zone for the Natufian distribution was the Euphrates Valley. Together with A. Moore, who described the stratigraphic and architectural remains from Abu Hureyra, D. Olszewski presented some ideas concerning the taxonomy of the lithic industry derived from the deposits. The comparison with Tell Mureybit, which lies only $20 \mathrm{~km}$ away on the opposite bank of the river, is inevitable. Cauvin (I982) and Calley (I986) suggest that there is no good reason not to include the lithic assemblage from Mureybet IA in the Natufian. This does not necessarily mean that the same can be said for Abu Hureyra (Olszewski 1986); it is not impossible that it was occupied by a different group with the same subsistence strategy as the preceding Epi-Palaeolithic hunter-gatherers of the region. The stratigraphic sequence at Mureybit, which leads to the Early Neolithic and resembles Khiamian and Sultanian sites in the southern Levant, indicates that there are real differences between the cultural sequences of these two mounds.

Technology. Several of the archaeological reports touched upon questions related to knapping methods, utilization of raw material, and typological variability. Two papers dealt specifically with the bone industry. D. Campana summarized his research on the bone industry from Hayonim Cave, while D. Stordeur discussed the large assemblage from Ain Mallaha (Campana I989, Stordeur I 988). Many of the Natufian bone tools were made by shaving, scraping, or incising with flint tools. Signs of utilization are evident on most pieces, and the piercing of soft materials seems to have been one of their most common tasks.

The results of intensive microwear studies were presented by R. Unger-Hamilton, who carried out systematic experiments with sickles both in Western Europe and in the Levant. Her suggestion (Unger-Hamilton I989) that the Natufians were the first farmers met with some challenge; participants generally wanted more direct evidence, such as carbonized plant remains. It was suggested that the large number of striations associated with the sickle gloss on Natufian sickle blades could have been caused by disturbance of the earth other than cultivation, such as yearly burning to enhance the natural growth of such annuals as cereals. The increase in the number of striations that is seen on Pre-Pottery Neolithic A and especially on Pre-Pottery Neolithic B sickle blades is perhaps explained as reflecting the establishment of farming communities. In this context P. Anderson-Gerfaud reported ongoing experiments in Berrias (a research center in the Ardèche directed by J. Cauvin) in replicating the techniques of early farmers in the northern Levant and Turkey. 
Population. The fossil Natufian populations were described and discussed by B. Arensburg and P. Smith. In Hayonim Cave there is a clear bias in the skeletal remains toward males (Henry 1989). The percentage of children (o-I 2 years old) is $22-30 \%$. Natufian life expectancy was around 32-35 years; the range of causes of death is still unknown. The population was healthy, and there are no clear indications of stress or of prolonged food shortages. According to Smith, a difference between Natufian and Neolithic populations in the Levant may be expressed in the width of the ramus of the jaw. The Natufians are more like hunter-gatherers than like farmers. The degree of dental attrition varies, however, with the sample; the Early Natufian sample from Kebara resembles hunter-gatherer samples while those from Ain Mallaha, Hayonim, and Nahal Oren resemble those from farming groups.

Subsistence. Various aspects of subsistence were described and discussed. It is very clear that the paucity of plant remains from Natufian sites does not reflect deficiencies in excavation techniques but is a real problem caused by the poor conditions of preservation at most of the sites excavated; flotation only slightly increases the size of the available samples. The few sites which do contain plant remains are Mureybet and Abu Hureyra on the Euphrates River, Wadi Hammeh 27 in northern Jordan, and Salibiya I in the Lower Jordan Valley. S. Colledge reported some finds from a series of EpiPalaeolithic sites from the Azraq Basin in Jordan (Garrard et al. I987). She suggested that tubers were preferred to seeds in this region during the Natufian.

The faunal remains seem to indicate that the Natufians hunted the species common in their environment. Thus at Mureybit the main species represented are gazelle and equids, with low frequencies of wild ox, rabbit, wild sheep, and fox. Evidence of stress on the gazelle population in the form of decrease in average size and increase in the frequency of younger animals was reported from Hayonim Cave and Hayonim Terrace by C. Cope and from Hatula by S. Davis (I989). J. Pichon (r984) compared the avifaunas of Mureybit, Ain Mallaha, and Hayonim Cave and reported that the various assemblages reflect both the nearby environments and more intense exploitation of waterfowl than in earlier prehistoric periods.

A. Sillen reported on a 1984 study using the ratio of strontium to calcium as an indicator of herbivorous as opposed to carnivorous diets. He admitted that the results probably do not reflect the true picture but register differences between sites. Additional studies are under way.

Assemblages of microvertebrates from Hayonim Cave have been studied by Tchernov (I984). Recent chromosomal and paleontological research by Aufrey and Tchernov (1989) indicates that during the Natufian wild mice (Mus spretoides) underwent a process of selfdomestication and became what is currently identified as Mus musculus domesticus, the house mouse. The prevalence of this species in Natufian microfaunal assemblages indicates an increase in human sedentism-a major change from the mode of life of the Late Palaeolithic hunter-gatherers known from Levantine cave sites. An additional self-domesticated species is the house sparrow (Passer domesticus). Thus Natufian sedentism is reflected by the overexploitation of gazelles and the presence of commensal species.

Art objects and marine shells. Natufian art objects are rare, and most of them have already been reported (e.g., Cauvin 1972). Belfer-Cohen described the as-yetunpublished engraved limestone slabs from Hayonim Cave, and Noy added a description of the small-animal skulls uncovered in Nahal Oren Terrace at Mount Carmel.

Marine shells, until not long ago a neglected subject, have received the recent attention of three researchers. D. S. Reese, reporting the finds from Jordanian sites, stressed the fact that although the shells often originate from the nearest coast, either the Mediterranean or the Red Sea, the rare finds from elsewhere are very interesting. For example, the presence at Ain Mallaha of Aspatharia rubens, a large freshwater mussel from the Nile, is an interesting indication of the distance that shells travelled through exchange networks (Mienis 1987). Most marine shells at the Natufian sites originated in the Mediterranean, and the assemblages are by and large dominated by Dentalium shells (Bar-Yosef I983). Many of these were used for body decorations, but large quantities are always found dispersed in the deposits wherever domestic activities were performed.

C. Perles and J. L. Phillips, serving as discussants, concentrated on the need for $(\mathrm{I})$ redefinition of the Natufian on the basis of the wealth of data now available and the large number of sites, which represent considerable lithic variability, (2) a search for evidence of sedentary communities in biological and archaeological, qualitative and quantitative sources, and $(3)$ the development of models that take into account the various reciprocal relationships among neighboring communities in terms of geographic orientation to the Euphrates River (i.e., northward), the Syro-Arabian desert (eastward), and the Sinai (southward). A combined and probably more complex socioeconomic model ought to be able to reconcile short-term residential mobility with the logistical mobility of task groups.

\section{References Cited}

A UFREY, J. C., AND E. TCHERNOV. I989. Origine du commensalisme de la souris domestique (Mus musculus domesticus) vis-à-vis de l'homme. Comptes Rendus de l'Académie des Sciences, Paris 307 (série 3):5 $17-22$.

BAR-YOSEF, O. I983. "The Natufian in the southern Levant," in The hilly flanks and beyond: Essays on the prehistory of southwestern Asia presented to R.I. Braidwood. Edited by C. T.

Young, P. E. L. Smith, and P. Mortensen, pp. I I-42. Oriental Institute Studies in Oriental Civilization 36.

. 1989. The PPNA in the Levant: An overview. Paléorient I $5: 57-63$.

BAR-YOSEF, O., AND A. BELFER-COHEN. I989. The origins of sedentism and farming communities in the Levant. Journal of World Prehistory 3:447-98.

BAR-YOSEF, O., AND N. GOREN. I973. Natufian remains from Hayonim Cave. Paléorient I:49-68. 
BELFER-COHEN, A. I988. "The appearance of symbolic expression in the Upper Pleistocene of the Levant as compared to Western Europe," in L'homme de Néandertal, vol. 5, La pensée. Edited by M. Otte, pp. 25-30. Liège: Études et Recherches Anthropologiques de l'Université de Liège 32.

BET TS, A. I982. Prehistoric sites at Qa'a Mejalla, eastern Jordan. Levant I4:I-34.

BOTTEMA, S., AND W. VAN ZEIST. I98I. "Palynological evidence for the climatic history of the Near East 50,000-6,000 years B.P.," in Préhistoire du Levant. Edited by J. Cauvin and P. Sanlaville. Paris: Centre National de la Recherche Scientifique.

BYRD, B. 1989. The Natufian: Settlement variability and economic adaptations in the Levant at the end of the Pleistocene. Journal of World Prehistory 3:1 59-98.

CALLEY, s. I986. Technologie du débitage à Mureybet, Syrie, $9^{e}-8^{e}$ millénaire. British Archaeological Reports International Series 3 I2.

CAMPANA, D. 1989. Natufian and Proto-Neolithic bone tools: The manufacture and use of bone implements in the Zagros and the Levant. British Archaeological Reports International Series 494.

CAUVIN, J. C. 1972. Les religions néolithiques de Syro-Palestine. Paris: Maisonneuve.

CAUVIN, M. C. I987. "Chronologies relatives et chronologies absolues dans l'Epipaléolithic du Levant nord," in Chronologies du Proche Orient/Chronologies in the Near East: Relative chronologies and absolute chronologies I6,000-4,000 B.P. Edited by O. Aurenche, J. Evin, and F. Hours, pp. 247-66. British Archaeological Reports International Series 379.

cow GILL, U. M. I969. The waters of Merom: A study of Lake Huleh. 2. The mineralogy of a 54-m core. Archiv für Hydrobiologie 71:42 I-74.

DAVIS, S. J. M. I989. "Hatoula I980-I986: Why did prehistoric people domesticate food animals?," in Investigations in South Levantine prehistory/Préhistoire du Sud-Levant. Edited by O. Bar-Yosef and B. Vandermeersch, pp. 43-6o. British Archaeological Reports International Series 497.

FEREMBACH, D. I976. Influence nutritionelle et différences morphologiques chez les populations préhistoriques (NatoufienIsraël). L'Anthropologie I4:I99-20I.

GARRARD, A. N., A. BETTS., B. BYRD, AND C. HUNT. I987. Prehistoric environments and settlement in the Azraq Basin: An interim report on the 1985 excavation season. Levant 19:5-25.

G AR R OD, D. A. E. I932. A new Mesolithic industry: The Natufian of Palestine. Journal of the Royal Anthropological Institute 62:257-70.

GORING-MORRIS, N. A. I987. At the edge: Terminal Pleistocene hunter-gatherers in the Negev and Sinai. British Archaeological Reports International Series 36I.

HENRY, D. O. I989. From foraging to agriculture: The Levant at the end of the Ice Age. Philadelphia:University of Pennyslvania Press.

LEROI-GOURHAN, A., AND F. DARMON. I987. Analyses palynologiques de sites archéologiques du Pléistocène final dans la vallée du Jourdain. Israel Journal of Earth Sciences 36:65-72.

MAGARITZ, M., AND G. GOODFRIEND. 1987. "Movement of the desert boundary in the Levant from latest Pleistocene to early Holocene," in Abrupt climatic change. Edited by W. H. Berger and L. D. Labeyrie, pp. 173-83. Berlin: Reidel.

MIENIS, H. K. I 987. "Molluscs from the excavation of Mallaha (Eynan)," in La faune du gisement natoufien de Mallaha (Eynan), Israël. Edited by J. Bouchud, pp. I 57-78. Mémoires et Travaux du Centre des Recherches Français de Jerusalem 4.

MOORE, A. M. T. I982. Agricultural origins in the Near East: A model for the I980s. World Archaeology I4:224-36.

NOY, T., I. SCHULDENREIN, AND E. TCHERNOV. I980. Gilgal: A Pre-Pottery Neolithic A site in the Lower Jordan Valley. Israel Exploration Journal 30:63-82.

OLSZE W S KI, D. I986. The North Syrian Late Epipaleolithic. British Archaeological Reports International Series 309.

PERROT, J., AND D. LADIRAY. I988. "Les sépultures," in Les hommes de Mallaha (Eynan), Israël. Edited by J. Perrot, pp. II06. Mémoires et Travaux du Centre des Recherches Français de Jerusalem 7.
PICHON, J. I984. L'avifaune natoufienne du Levant. 2 vols. Thèse de $3^{\mathrm{e}}$ cycle, Université Pierre et Marie Curie (Paris VI), Paris, France.

SCHULDENREIN, J., AND P. GOLDBERG. I98I. Late Quaternary paleoenvironments and prehistoric site distribution in the Lower Jordan Valley: A preliminary report. Paléorient 7:57-72. Sc OT T, T. R. I977. "The Harifian of the central Negev," in Prehistory and paleoenvironments in the central Negev, Israel, vol. 2, The Avdat/Aqev area, pt. 2, and the Har Harif. Edited by A. E. Marks, pp. 27I-322. Dallas: Southern Methodist University Press.

SILLEN, A. I984. Dietary variability in the Epipaleolithic of the Levant. Paléorient IO: I 49-55.

SOLIVERS-MASSEI, O. I988. "Etude anthropologique," in Les hommes de Mallaha (Eynan), Israël. Edited by J. Perrot, pp. I09-208. Mémoires et Travaux du Centre des Recherches Français de Jerusalem 7.

STORDEUR, D. I 98I. La contribution de l'industoire de l'os à la délimitation des aires culturelles: L'exemple du Natoufien," in Préhistoire du Levant. Edited by J. Cauvin and P. Sanlaville, pp. 433-38. Paris: Centre National de la Recherche Scientifique. . I988. Outils et armes en os du gisement natoufien de Mallaha (Eynan), Israël. Mémoires et Travaux du Centre des Recherches Français de Jerusalem 6.

TCHER N OV, F. I984. "Commensal animals and human sedentism in the Middle East," in Animals and archaeology, vol. 3, Early herders and their flocks. Edited by J. Clutton-Brock and C. Grigson, pp. 9I-IO5. British Archaeological Reports International Series 202

UNGER-HAMilton, R. 1989. The Epi-Palaeolithic Southern Levant and the origins of cultivation. CURRENT ANTHROPOLOGY 30:88-103.

VALLA, F. I984. Les industries de silex de Mallaha (Eynan) et du Natoufien dans le Levant. Mémoires et Travaux du Centre des Recherches Français de Jerusalem 3.

VAN ZEIST, W. I988. Some aspects of Early Neolithic plant husbandry in the Near East. Anatolica 1 5:49-68.

\section{Earliest Gold Artifacts in the Levant ${ }^{1}$}

\section{A. GOPHER, T. TSUK, S. SHALEV, AND R. GOPHNA Institute of Archaeology, Tel Aviv University, Ramat Aviv 69978, Israel. 26 II 90}

Archaeological excavation in Nahal Kana Cave, discovered in the early 1980 s and investigated in $1986-88$ by a team from Tel Aviv University, has revealed a Chalcolithic (4th-millennium-B.c.) cemetery of a scale and complexity hitherto unknown in the period. Eight gold artifacts discovered in one of the graves (fig. I) are the earliest yet to be found in the Levant. Their discovery

I. (C) I990 by The Wenner-Gren Foundation for Anthropological Research. All rights reserved oor I-3204/90/3 I04-0004\$1.00. The study of Nahal Kana Cave was made possible by grants from the Israel Ministry of Science and Development (grant no. 7I06) and support from the the Centre of Speleological Research of the Society for the Preservation of Nature in Israel. Our thanks are due to P. R. S. Moorey, J. P. Northover, C. J. Raub, Gal-Or, and D. Schechterman for their professional advice and to S. A. Rosen, T. Levy, A. N. Goring-Morris, N. Goren-Inbar, and E. Orrelle for reading early versions of this paper and offering valuable comments. D. Enoch and $\mathrm{D}$. Ladiray prepared the drawings, and the photographs were taken by $\mathrm{Z}$. Radovan. 